
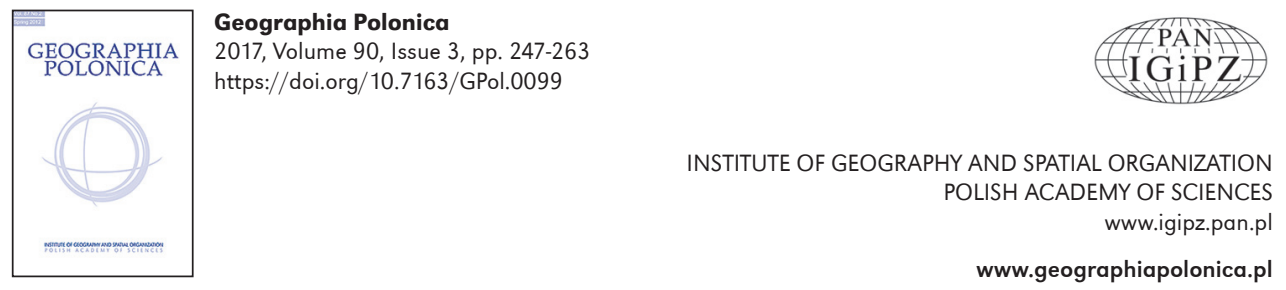

\title{
SOCIAL AND TRANSPORT EXCLUSION
}

\section{Václav Jaroš}

Department of Social Geography and Regional Development, Faculty of Science

Charles University

Albertov 6, CZ- 12843 Praha 2: Czech Republic

e-mail: vaclav.jaros@natur.cuni.cz

\begin{abstract}
The presented article focuses on the relationship between social exclusion and the transport geographical characteristics which are considered as instrumental in the development of social exclusion, and also as a negative feature that can even deepen the exclusion. In the first part, the author generally defines and examines the concept of social exclusion as a selectively operating process of differentiation, the way it has been perceived over time and its individual aspects with an emphasis on the spatial dimension. The second part of the article is devoted to the conditional relationship between transportation and social exclusion. Besides the description of this process of exclusion, which is transport related, there is a discussion of the role of transport (in)accessibility and characteristics of personal mobility as a crucial factors which cause or intensify the exclusion. On the other hand it also offers a chance to reintegrate individuals into society.
\end{abstract}

\section{Key words}

transport exclusion $\bullet$ social exclusion $\bullet$ poverty $\bullet$ accessibility $\bullet$ mobility $\bullet$ transport disadvantage $\bullet$ transport inequality

\section{Introduction}

At present, the concept of social exclusion regarding the particular limitations of individuals or groups in terms of their participation in social events/activities is already fully established. It is amply reflected across the social sciences and in the sphere of public administration and regional development and social policy on various (global, macroregional, mesoregional, microregional, local and even individual) levels (Townsend 1979; Sibley 1995; Silver 1995; Levitas 1996; Burchardt et al. 1999; Atkinson 2000; Mareš 2000; Rabušic 2000; Ratcliffe 2004). Within the framework of the study of social inequalities, social disparities or the differentiation and polarisation of society, this is a crucial concept at present (Levitas 2006; Pirani 2013). Social exclusion can take various forms, depending on the main factors and mechanisms that cause, accompany or even magnify this process 
(Percy-Smith 2000; Kenyon et al. 2002; Mareš $2002)^{1}$. Due to these factors, specific individuals or groups are limited or even excluded from participation in social activities. Insufficient integration of individuals or groups into a transport system can also be one of the factors/mechanisms underlying social exclusion: this can be considered one of the causes of exclusion or, on the contrary, as a negative manifestation that intensifies the exclusion (Church et al. 2000; Kenyon et al. 2003; Preston \& Rajé 2007; Hine 2008; Lucas 2012). Although transport geographers (especially in Anglo-Saxon countries) have been intensively engaged in this topic for the last two decades (Lucas et al. 2001; Hine \& Mitchell 2003; Kenyon 2011) the nature and the complexity of the relationship between social exclusion and characteristics of accessibility and individual mobility have not been sufficiently explained. This approach to the study of transport inequalities may still be considered innovative and in many countries (especially Central and East European) this issue of transport geography is mostly ignored and not reflected.

This article outlines a general (theoretical) look into the conditional relationship between transportation and social exclusion. Specifically, the article seeks to outline the role of transport (in)accessibility and characteristics of mobility within the framework of the concept of social exclusion. The topic is conceptualised here, set into a broader theoretical framework of the concept of social exclusion and, in addition to this treatise, also discusses various approaches to the study of this process. The article is divided into two main parts. The first part (chapters: 'Social exclusion and poverty' and 'Dimensions of social exclusion') is devoted to the definition of the basic concepts associated with the social stratification of society with an emphasis on the evolution of the concept of social exclusion over time. Particular attention is paid to the spatial dimension of social exclusion. The second part (chapter: 'Transport and social exclusion')

1 For more on the forms and dimensions of social exclusion, see chapter 'Dimensions of social exclusion'. focuses on the factor of transport (accessibility and mobility) and the ways it can potentially contribute to social exclusion. The end of the article presents various ways in which the conditional factors of transport in this process can be identified and how they may also distinguish areas with a potential for developing transport-related social exclusion according to their various types. In the article, the whole topic is systematically examined within the context of the pre-existing published literature and research, providing the opportunity for a broad theoretical framework.

\section{Social exclusion and poverty}

Over the course of the past 30 years, the concept of social exclusion has become one of the fundamental pillars of social and political discourse on various levels (for more see, e.g., Levitas 2006; Pirani 2013). Social exclusion in academic research as well as documents concerned with regional development or social policy have gradually replaced the concept of poverty used until the late 1970s, which dealt with extreme cases of social inequality (Parkin 1971; Townsend 1979; Levitas 1996; Rabušic 2000; Pirani 2013). However, due to its 'static nature', the concept of poverty did not fully encompass the essence and growing complexity of the described phenomenon (or more precisely, of the process): the problem of social inequalities and all their dimensions. In general, one can describe the concept of social exclusion as a process of social deprivation, in which individuals or groups which are members of the society do not have any chance to fully participate in the activities that are common in that society - activities to which they are fully entitled as its members ${ }^{2}$ - while the causes of this limitation

\footnotetext{
2 The entitlement arises from individuals' objective rights to use the advantages offered to him/ her by membership of the society, specifically to the extent that is usual in the society. The individual can apply his/her membership of the society on the basis of citizenship, being part of an ethnic, racial, religious or other group, or possibly also on the basis of being part of humanity and thus, he/she may claim his/her human rights.
} 
cannot be directly influenced by the individual or the group (modified according to Burchardt et al. 1999; Church et al. 2000). Levitas et al. (2007: 9), e.g., defines social exclusion as: “(...) the lack or denial of resources, rights, goods and services, and the inability to participate in normal relationships and activities, available to the majority of people in a society, whether in economic, social, cultural or political arenas. It affects both the quality of life of individuals and the equity and cohesion of society as whole".

The nature of the mechanisms (form, method and causes) of such an exclusion can be quite varied (for more see, e.g., Percy-Smith 2000; Mareš 2002; Ratcliffe 2004; Levitas 2006). The conceptualisation of the notion itself first occurred within the field of sociology ${ }^{3}$, which defines social exclusion particularly as stemming from the fragmentation of society, primarily in its vertical dimension (Petrusek 1996). Other social sciences are based on this definition, and therefore their approach mainly differs in terms of the subjects of the research conducted within the individual disciplines.

In these connotations, poverty in its absolute (material) conception as the minimum level of subsistence is no longer (in the late 1970s) the essential problem of social inequality, as there is a shift of meaning towards a more relativistic perception of poverty. This is understood as a state in which a person, household or whole groups of households lack resources (financial, material or otherwise) that would allow them to fully participate in the activities of society, that their living conditions and material standards would be at the common level in the society. As a result, there is an impossibility to approach the social standards associated to any particular social referential framework (Townsend 1979). This was especially clear in the societies of late capitalism in Western Europe at the time (the

3 The sociological dictionary (Petrusek 1996) defines social exclusion as follows: this is a "mechanism or strategy by means of which one group protects its privileges and advantages by closing access to resources to other groups(...)" (Petrusek 1996: 294). 1970s) when the material concept of poverty no longer fully described the reality of problem ('deprived') areas and of social inequalities in society in general. On the other hand, it was much easier to see the problem of their overall failure to be integrated into the system, processes and structures of society. This brought about a spatial segregation ${ }^{4}$ or marginalisation that was no longer based solely on the social stratification of society according to economic viewpoints (in particular the position on the labour market, unemployment, real household incomes, etc.), but other viewpoints (non-economic in particular ${ }^{5}$ ) also applied.

Within the framework of research into social inequalities, poverty began to be seen as an impact or an exactly measurable sign of the vertical differentiation of a society (Atkinson 2000). By contrast, the new concept of social exclusion represents a discursive turning point. From a clearly measurable concept of poverty, whose objective is to identify, quantify or perhaps to interpret inequalities in a given society, the focus shifts to the concept of social exclusion ${ }^{6}$ which seeks to understand the substance of social inequalities itself and its appearance, development and/or the possibility to face it. By including the social differentiation of a society in its entirety, the definition of social exclusion itself remains elusive and it is difficult to define the term both exactly and simply at the same time. In fact, it is a heuristic concept which provides a platform for the discussion of the issue of social inequalities and inequities rather than an exactly defined and measurable term (Růžička 2006).

However, the replacement of the concept of poverty by the concept of social exclusion

\footnotetext{
4 In some aspects, the mentioned spatial segregation can be perceived as a supreme form of the process of social exclusion (e.g., Ratcliffe 2004).

5 Ethnic, cultural, religious, but also spatial viewpoints, etc. (see, e.g., Percy-Smith 2000; Kenyon et al. 2002).

6 These concepts focus on the dynamism, multidimensionality and pluralism of interrelated processes (Lucas et al. 2001; Lucas 2012), which explain the inequalities or, more precisely, injustice in society from the viewpoint of both causes, and impacts.
} 
in developed countries does not mean that poverty no longer occurs there. On the contrary, the conceptual change was prompted by the growth in poverty in Western Europe in the latter half of the 1970s and especially by the way it was modified. For a long time, there was a general consensus (shared especially by politicians) that a state of affairs would be reached ${ }^{7}$ in which poverty would no longer exist in advanced societies (Ringen 1988). These ideas were based on divergence theories of regional development for which increasing inequalities are manifestations of the natural development of society. They point out the fact that although living standards and material wealth may be rising at different rates, all sectors of society continue to grow. Just the unequal growth in living standards brought about a change in the perception of the notion of poverty, which was no longer solely associated with the provision of basic needs (physiological and security ${ }^{8}$ ) of the individual or the aforementioned purely material concept concerning the minimum level of subsistence (the absolute meaning of the concept of poverty).

In its original conception, the phenomena of poverty only occur quite rarely in developed European countries. There is no longer physical hardship ${ }^{9}$, but there is social hardship that arises from the impossibility of achieving social standards related to the social framework of reference, which can be perceived as a form of relative poverty (Townsend 1979). Poverty in the 'Townsendian' relative conception includes the elements of social exclusion and is all but identical with the present-day perception of economic exclusion as one of the dimensions of social exclusion (e.g., Percy-Smith 2000; Kenyon et al. 2002). As a result, although poverty (economic exclusion)

\footnotetext{
${ }^{7}$ Due to economic growth and the suitable response of the social welfare system, automatic stabilisers in the economy, and a generally growing volume of transfer payments.

8 See Maslow's hierarchy of needs (Maslow 1970).

9 Even people from the poorest parts of society (e.g. homeless people) are for example not exposed to the threat of famine, contrary to the past.
}

is one of the essential forms of social exclusion, it cannot be directly linked as a necessary cause (condition of the appearance) of social marginalisation. On the contrary, insufficient access to resources and material assets of a society are seen as a consequence of excluding individuals or groups from that society. This leads to the realisation that it cannot be said that poverty is the cause of social exclusion. Instead, it is its negative manifestation (Růžička 2006). ${ }^{10}$.

According to Mareš (2000), during the shift from the concept of poverty to the concept of social exclusion there was not only a replacement of the notions, but also a change in the very substance of the object of interest. It is no longer possible to only focus on the distribution of wealth in society, as there is a need to pay attention especially to the "weakening of the ties that hold society together" and to the associated questions of its coherence and social cohesion (Mareš 2000: 286). One can see this as a shift of the centre of gravity of a focus on vertical inequalities in society towards horizontal inequalities based on ethnic, cultural or religious differences and many other ${ }^{11}$ viewpoints, including spatial ones. This conceptual shift is perceived in the same spirit by Giddens who states that "the concept of social exclusion does not deal with escalating inequalities, but with the mechanisms which eventually separate certain groups from the mainstream society" (Giddens 1998: 104). As a result, there is a horizontal division into those 'inside' and 'outside' a society rather than its vertical split in the sense of 'up' and 'down' (Giddens 1998; Burchardt et al. 1999). In fact, this is a shift from the dichotomy of 'the rich versus the poor' to the dichotomy of 'included in versus excluded' from a society.

10 One cannot consider both notions as synonymous because socially excluded individuals need not be poor as well. By the same token, if an individual is poor, he/ she need not necessarily be socially excluded.

11 Other viewpoints could include: social status, the human and social capital of the individual, sexual orientation as well as health, age, gender and other factors. 
Social exclusion is an extreme sign of the internal heterogeneity of a given community and its social inequalities. However, since they appear in various forms in all societies, they can be considered as natural. They only become a problem at the moment when the existence of such inequalities in a society cannot be justified ${ }^{12}$ in an acceptable way. Excessive social inequalities can then threaten social reconciliation, social cohesion and, therefore, the development of the society as well. The problem manifests itself as a social disadvantage, which, as a rule, relates to the people and groups in a minority or even marginal position or which are insufficiently integrated into society. This raises the question of the overall relationship of the excluded individuals to society. Does their exclusion mean that they are pushed completely outside society or 'only' to its margins? If individuals or groups are totally excluded from a society, this means that they do not figure in the system and structures at all. ${ }^{13}$ On the other hand, the individuals and groups who are pushed to the margins of society share the value system, including all the ethical, cultural and social patterns, with the majority, but they are unable to change or improve their minority position. While exclusion outside society creates its own cultural patterns, exclusion to the margins of society rules out such an alternative. In this context, mention is often made of 'the culture of poverty' (Lewis 1966), but according to Bauman, such a culture cannot be distinctive or of a durable character because "sharing a trauma does not make any brothers from the suffering people" (Bauman 2001: 121).

Taken as a whole, one can state that inequality of conditions, limitation of access to resources or the profits from them as well as limitation of a share in power to some individuals or groups can be considered as a fundamental

12 The existence of inequalities must be justifiable (reasonable) and must not exceed a certain limit that guarantees social stability.

${ }^{13}$ Such individuals or groups do not share the value system or social, cultural and ethical behavioural patterns with the society, but they create them for themselves in parallel towards the majority society. condition of the functioning of human society which enables it to develop. On the other hand, resources or profits from excessive polarisation and the unsubstantiated concentration of power in a certain segment of society can simply become a mechanism or strategy for the dominating groups to maintain or enhance their position in society.

Within the conceptual framework of the topic at hand, one can track three different approaches which influenced the wider definition of social exclusion in the early 1980s Anglo-Saxon, French (Continental) and Marxist (European Left).

The Anglo-Saxon 'liberalist' ideological current arises from Townsend's aforementioned concept which assumes that low living standards cause social isolation, preventing those affected from participating in the activities which are common in a society. In this context, an emphasis is placed on the connection between social exclusion and social closure. ${ }^{14}$ One can speak about the social exclusion ${ }^{15}$ of individuals and groups on the one hand, and also about the usurpation of scarce resources on the other ${ }^{16}$ (Parkin 1971; Petrusek 1996; Rabušic 2000). In the Anglo-Saxon concept, individuals act as competitors who clash especially in the labour market. As a result, one can see a solution to social exclusion in the support of the competitiveness of individuals or groups which are most disadvantaged in the labour market. According to Levitas (1996), this is a sort of pseudo-Durkheimian conservatism subordinated to the neoliberal economic discourse in which paid work is the primary mechanism of cohesion of society and integration is thus primarily

14 This can be described as a strategy of individual groups in society with a view to actively limit the access of others to resources and power.

15 The concept of an 'underclass', used in the USA, is analogous to the Anglo-Saxon 'poverty based' concept of social exclusion.

16 Within the framework of sociology, usurpation and social exclusion are often understood as two mechanisms through which social exclusion of the society or community is reached or is maintained over a long period of time, while usurpation need not be a mechanism that is solely used by majority society (Parkin 1971). 
possible through the labour market (see Levitas 1996 or Atkinson 2000). ${ }^{17}$

On the other hand, the French (Continental) approach focuses on this topic from the viewpoint of the role of society in the life of the individual. Society, in this context, is represented by the state (Rabušic 2000). This concept arises from the French republican tradition, within which social exclusion is primarily understood as a failure of the state to fulfil its mission. This being, among other things, the integration of all of its citizens into the social order and the provision of the chance to participate in its functioning. This leads to the weakening of social links in society and its disintegration or fragmentation, resulting, therefore, in a systematically-conditioned process of marginalisation (Strobel 1996). As with the Anglo-Saxon model, the French ideological current focused primarily on the integration of marginalised individuals or groups into the labour market as the main mechanism to ensure social cohesion.

Along with the Anglo-Saxon and French schools, one also has to mention the third current which considerably influenced the conceptualisation of social exclusion as a crucial process of marginalisation. Based on the Marxist concept, the school of the European Left perceives social exclusion as arising from the monopoly of certain groups on the sources of power and influence in society (Mareš 2000). In doing so, it stresses the hierarchy of power in society as a factor which prompts the creation of social discrepancies. In the theory, the enforcing role of the social order as defined by Max Weber (e.g. in Silver 1995) is the main mechanism by which exclusion occurs. While the Anglo-Saxon concept arises from the paradigm of specialisation and the French concept from the paradigm of solidarity that of the European Left primarily arises from the paradigm of monopolisation (e.g. Silver 1995). However, all three concepts basically arise from a structuralist perception of the

\footnotetext{
17 The same author argues with some exaggeration that social exclusion so conceived is only a more attractive form of the original concept of poverty (Levitas 1996).
}

world, primarily differing in the way in which the structures of society fail (individual-statehierarchy of power). ${ }^{18}$

In connection with social exclusion, mention is often made of the concepts of social cohesion and social inclusion. ${ }^{19}$ However, in this sense they cannot be perceived as being quite autonomous because their substance arises from the concept of social exclusion itself, they are directly derived from it. Since this is a relational relationship, the concepts of social cohesion and social inclusion can be described as societal principles or ideas which are defined by the efforts to mitigate negative manifestations of social differentiation (marginalisation) processes.

\section{Dimensions of social exclusion}

In connection with the process of social exclusion, according to Mareš, one can identify six different dimensions (see Tab. 1). In their essence, they present ways in which individuals or groups are disadvantaged. In fact, these are some of the forms of exclusion (Mareš 2002). Different classifications are presented, e.g., by Percy-Smith (2000), who outlines seven dimensions, and Kenyon et al. (2002), who has as many as nine. The last-mentioned author distinguishes them in a direct or indirect relationship to the topic of transport accessibility and mobility (Kenyon et al. 2002). Despite this, the approaches of these three authors are very similar and one can find clear parallels in them, as is obvious in the comparison made in Table 1.

The economic dimension is most frequently denoted as vital as it is the simplest one and can be defined most accurately as it is measurable and its manifestations in society are

\footnotetext{
18 From the 1980s on and especially in the 1990s, the individual concepts (the Anglo-Saxon and French in particular) were gradually merging, especially under the influence of the institutionalisation of the topic of social exclusion within the European Economic Community and later in the European Union (Atkinson 2000; Rabušic 2000; Růžička 2006).

19 At present, these concepts are widely applied especially in the sphere of social and regional policy, specifically on various levels.
} 
Table 1. Dimensions of social exclusion - a comparison

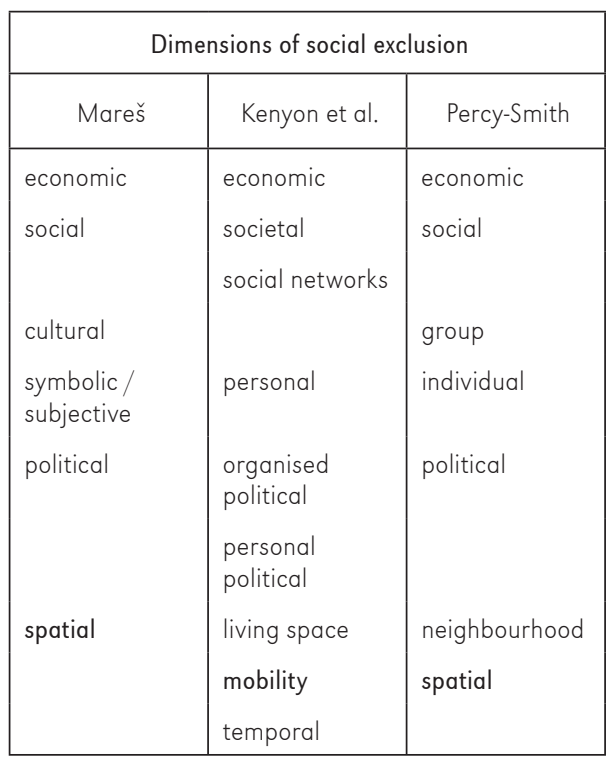

Sources: Percy-Smith (2000); Mareš (2002); Kenyon et al. (2002).

usually the most pronounced. For this reason, all the other described forms of exclusion are by some scholars perceived only as 'subdimensions' of the same (economic) process (Rủžička 2006). ${ }^{20}$ In its essence, economic exclusion can be identified with the above-mentioned 'Townsendian' concept of poverty. Although this is the main and clearly substantial form of social exclusion, it cannot be directly seen as the primary cause of social exclusion or as an underlying factor in its development. By contrast, insufficient access to resources and material assets of a society (Townsend 1979) is a consequence of the exclusion of individuals or groups from society. This stems from the argument that one cannot state that poverty is a cause of social exclusion. Instead it is a manifestation that signals the existence of social exclusion.

The social dimension reflects the lack of involvement or the total exclusion

${ }^{20}$ In addition, they are seen as directly determined by this process. of an individual or group from social networks, which could be used to improve their social status. The social mobility of the excluded individual is then limited to the networks of the groups that find themselves in the same position (also socially excluded). In such networks, strong interpersonal links (inside the network) overshadow weak interpersonal links (those between networks). ${ }^{21}$ This results in the constant circulation of the same information within a particular network.

The cultural dimension is analogous to the social dimension, but focuses more on the disharmony of the individual's cultural capital with the majority society, on the basis of which the individual's chance to participate in the activities that are common in a society is limited. The social and cultural, but also group dimensions $^{22}$ are most often revealed through the limitation of access of certain groups to education and also, e.g., through a breakdown of traditional households, unwanted teenage pregnancies, homelessness and crimes committed by disaffected youths (Percy-Smith 2002).

The political dimension reflects the (im)possibility of an individual or group to take part in the decision-making in public affairs. There is a limitation of civil, political or fundamental human rights. It is made clear in all three concepts depicted in Table 1 that within the framework of political exclusion, the individual or group is limited on two levels: the limitation of influence on society and the limitation of influence over one's own life.

Social exclusion has two other dimensions: the personal and the individual, with a focus on the individual and the current physical and mental state of the individuals which determines their chances to be integrated into majority society (Percy-Smith 2000; Kenyon et al. 2002). The symbolic dimension, also called subjective, reflects the exclusion of individuals

\footnotetext{
${ }^{21}$ For more on the concept of strong and weak interpersonal links see Granovetter (1973).

22 This is an accumulation of risk factors of exclusion appearing in certain groups of the population (as a rule, those with a lower vulnerability) such as teenagers, ethnic minorities or people with special needs.
} 
by means of marginalisation or even stigmatisation. This is based on the opinion of the majority society which is often affected by stereotypes and prejudices towards the excluded.

\section{Spatial dimension of social exclusion}

A specific position is assumed by the spatial dimension, especially from the viewpoint of social geography. Its essence is well described by Foucault's argument that "our time is the time in which space acquires the form of relationships between emplacements" ${ }^{23}$ (Foucault 1996: 73). This was already highlighted by Durkheim along with his disciple Mauss who stressed the social conditionality of the organisation of physical space. As a result, spatial patterns directly reflect the social structure of a given society (Durkheim \& Mauss 1963 cit. in Rưžička 2006). For this reason, the problem of social exclusion can only be studied in the context of spatial aspects of this process. Describing the notion of social exclusion, The Dictionary of Human Geography (Gregory 2009: 751) says that this is a process that is simultaneously both social and spatial and should be examined as such in geography. According to the theories of social interactionism, the substance of social exclusion itself arises from the essential ${ }^{24}$ definition of ' $U s$ versus Them'. This is a classification derived from the primary classification of 'I versus Others', that was gradually applied to society and subsequently to space as well, during the course of socialisation (Sibley 1995). Sibley defines this as a socio-spatial exclusion.

Within the framework of the spatial dimension (Tab. 1), Mareš (2002) identifies the basic problem as one of the accumulation of risk factors in a specific locality such as crime, pollution, insufficient community amenities

23 Foucault defines emplacements as relationships of closeness between points or elements, while technically the relationships can be described as series, trees or networks (Foucault 1996).

24 Essentialism separates social formations on the basis of their supposed essence, or some outwardly installed quality, becoming the main strategy of exclusionism (Růžička 2006). and transport accessibility and possibly also bad infrastructure. ${ }^{25}$ By contrast, Kenyon divides these spatial aspects into the dimension of lived space in which she includes (as in the case of the previous authors) factors associated with the quality of the local environment, the quality of housing, crime and community amenities. In addition, she defines the unique dimension of mobility which includes specific factors of social exclusion based on insufficient access to transport or insufficient inclusion of specific individuals in the transport system (Kenyon et al. 2002). The described dimensions which take into account spatial, positional and accessibility factors assume a unique position among other dimensions because they can considerably magnify the influence of other individual factors, thus deepening social exclusion.

On the other hand, the increased mobility of individuals (or possibly also of goods and services) as well as the development of 'virtual mobility' or improvements in accessibility to services, goods, labour opportunities, social contacts and other crucial aspects can be an efficient instrument to mitigate the negative features ${ }^{26}$ of social exclusion. However, one also has to take into consideration the fact that as a rule these factors have a selective impact on the residents of a locality. This means that there can be some individuals whose disadvantaged status towards the social referential framework will paradoxically become even worse. Therefore, one can state that in the context of the given topic, social geography primarily deals with the spatial or socially spatial dimension as a factor which considerably supports differentiating processes of social exclusion (Musil \& Müller 2008). In this concept, social exclusion not only has an impact in terms of social stratification, but

\footnotetext{
25 In this sense, Percy-Smith refers, together with the spatial dimension, to a community dimension as well. This includes the devastation of the human environment, the collapse of supportive measures or the inaccessibility of services (Percy-Smith 2000).

26 For example, unemployment, low living standards, crime, unfair access to education or health care, etc. can be denoted as specific negative features of social exclusion.
} 
spatial aspects of differentiation in the form of regional disparities (Chromý et al. 2011) also come to the foreground. Regarding social stratification, along with the transformation of vertical social inequalities into the horizontal (spatial) dimension, there is the social and spatial isolation of individuals or groups from the mainstream society ${ }^{27}$. This can occur for various reasons and in various ways. According to Mareš, this threatens social cohesion and the coherence of society as a whole ${ }^{28}$, while he defines four basic factors that denote the ways in which social exclusion can occur (Mareš 2006: 6):

- Refusal by majority society to integrate individuals or collectives.

- Refusal of certain individuals or collectivities to be integrated along with the tendencies to reject the majority society and to create communities that differ in terms of their culture, language or religion (or the community itself creates borders or even barriers).

- Personal characteristics of the excluded individuals and the incompatibility of their (economic, social or, e.g., educational) capital with the majority society.

- Structural factors (or value factors) preventing individuals or collectivities from integrating themselves (independently from their will to be integrated and from the will of majority society to integrate them).

The described factors are conceived in their relationship to social exclusion in general, but they also have an impact on the spatial differentiation of a society in the form of segregation or separation (depending on the underlying factors). It is these factors combined with the emergence of peripheral or other 'problem' areas which can then be seen as mechanisms for the occurrence of social exclusion,

27 The notion of mainstream society is analogous to the social standards related to a given social framework of reference described by Townsend (1979).

28 This occurs in processes that promote the segregation of problematic residential locations (such as housing estates), ghettoisation of streets or even parts of cities, or the consolidation of large peripheral areas which does not offer its inhabitants conditions comparable to social standards. while also acting as its negative manifestation in space (Musil \& Müller 2008). These areas have one basic feature: insufficient integration into the social structures, processes and systems dominating in a given time and space (Schmidt 1998 cit. in Havlíček \& Chromý 2001). Specifically, they do not reach a certain level of functional and spatial as well as sociospatial relationships.

As a rule, interactions with the core areas (the majority of society) are insufficient and are unilaterally oriented (dependence on the core). In general, one can state that social exclusion is a social process of differentiation of a society rather than an immanent quality of a certain region (Musil \& Müller 2008). Social inequalities do not directly appear in this process as they are only reproduced onto a different (higher) level where inequality is transformed into a disadvantaged status, thus becoming a social problem. In this sense, one must focus on the fact that social exclusion is not a result from any differentiation of society, but that it is a complicated, selective differentiating process, within the framework of which the original spatial differentiations of a society are even more deepened or reproduced.

\section{Transport and social exclusion}

In the past decades, Czech and foreign transport geographers have paid close attention to the topic of transport accessibility, mobility and associated issues such as modal choice, transport justice, etc. (Nutley 1998; El-Geneidi \& Levinson 2006; Marada \& Hudeček 2006; Komornicki et. al. 2010; Seidenglanz 2010; Kraft 2012; Stępniak et al. 2013) especially in connection with the development of the 'new mobility paradigm' (e.g., Sheller \& Urry 2006). The described studies view the (non) inclusion of an area and the people who live there in the transport system as the main problem. According to Knowles, these topics are among the ten most significant problems being addressed by transport geography in the 21st century (Knowles 1993). Unlike this concept, in which the topic of accessibility and mobility is limited to an examination 
of transport geography systems, their development, underlying factors, the position of individual elements in them and their behaviour, approaches setting the whole topic in a wider context began to be applied in the AngloSaxon environment. They stress the relationship to the concept of social exclusion and its spatial (mobility) dimension, described in the previous chapter (Church et al. 2000; Lucas et al. 2001; Kenyon et al. 2002, 2003; Hine \& Mitchell 2003; Preston \& Rajé 2007; Hine 2008; Delbosc \& Currie 2011; Engels \& Liu 2011; Kenyon 2011; Lucas 2012; Shergold \& Parkhurst 2012; Mackett \& Thoreau 2015; Schwanen et al. 2015).

Systematic research into the problem of social inequalities, based on the aspects of transport (in)accessibility and mobility, was enhanced by its institutional anchoring in the form of the 'Social Exclusion Unit' $(\mathrm{SEU})^{29}$. This is an advisory body of the prime minister of the UK (e.g., SEU 2003) which focuses on the transport system as a factor enabling the population of localities with a disadvantaged location (with an exposed character) and how to integrate them into society. It has turned out that insufficient inclusion in a transport system is a considerable barrier which has a selective effect on individuals, making it impossible for them to fully participate in social activities (Kenyon et al. 2002; Preston \& Rajé 2007; Hine 2008; Mackett \& Thoreau 2015). As the social exclusion described in such a way largely depends on transport, one can speak about transportrelated social exclusion or, more precisely, transport exclusion. This is a complex differentiation process, within which an individual or a group of individuals who are members of a given society do not have a chance to fully participate in routine activities to which they are entitled as members of the society. This limitation is caused by the inaccessibility of transport to these activities. As a result, there is a limited or barred access to activities

29 In 1997, the SEU replaced the original government advisory body called the Social Exclusion Task Force (SETF). For more information see, e.g., Lucas (2012); SEU (2003). common in a society on the basis of how far the location is from the destination, poor access to transport and/or insufficient mobility of the individual (Burchardt et al. 1999; Church et al. 2000; Kenyon et al. 2002; Hine 2008). Therefore, in the case of transport exclusion, the problem is not posed by any lack of opportunities, but by their inaccessibility (Preston \& Ráje 2007).

The concept of transport exclusion contains two vital aspects, (a) social and (b) transport, (generally outlined in Fig. 1). The social aspect (a) is represented here by social exclusion which represents a real disadvantage for the individual in his/her everyday life (such as access to the labour market, education, health care, services, or limitation of social and cultural relationships of the individual, etc.) (Kenyon et al. 2002). There are a variety of features describing the process of social exclusion with a direct impact on the residents' lives. On the other hand, the transport aspect (b) reflects the transport conditionality of social exclusion itself. These are specific barriers that cause or magnify the disadvantage, being represented by accessibility and mobility (see Fig. 1).

Accessibility, or transport accessibility, means the ability to reach a given locality from other localities or the ability to reach other localities from a given locality by means of a transport network (Rodrigue et al. 2006). Within the framework of accessibility, there are 'forces of gravitation' which constitute the attractiveness of a given place (which means that the place offers quantitatively or qualitatively different conditions than the source locality or there is a certain reason to carry out the trip). There are also 'forces of resistance', constituted by the specific barriers an individual must overcome during a journey (distance, time, financial costs, or frequency) (El-Geinedy \& Levinson 2006). Accessibility determines the 'external frameworks' of transport exclusion. This means that, in this case, a role is played by the factors of the distance of the location (exposed character) and transport (in)accessibility 


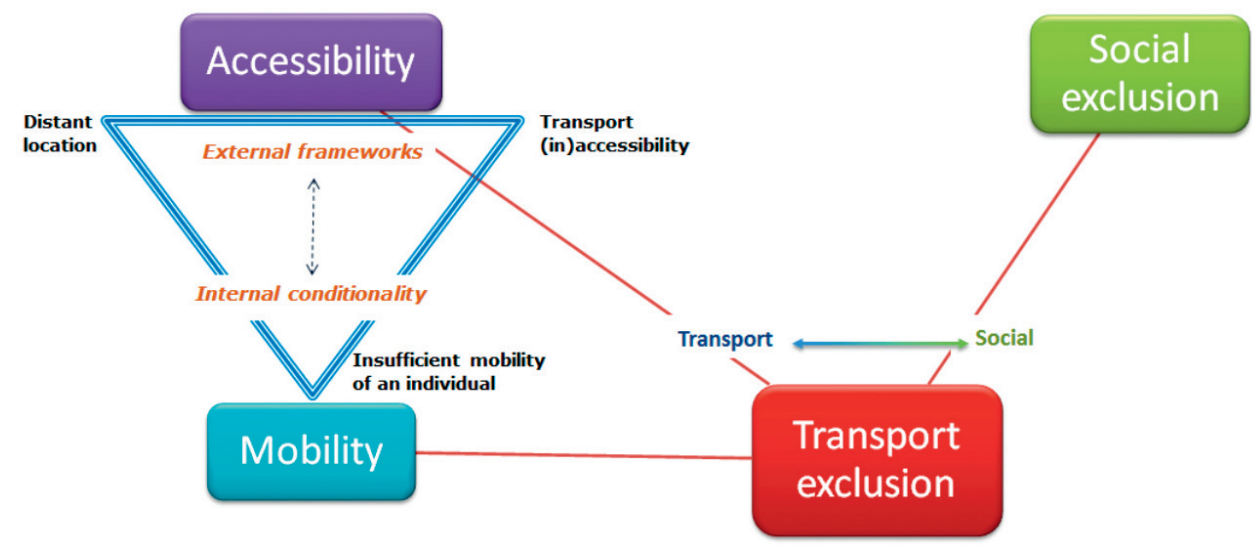

Figure 1. Transport exclusion - transport and social aspects; internal conditionality and external frameworks

(see Fig. 1) which are given for a locality and are identical for all of its residents.

By contrast, mobility (personal mobility) defines the 'internal conditionality' of transport exclusion. It provides the opportunity or ability for a specific individual to be transported. This is an absolutely individual factor which fully depends on the specific (transport) needs of every individual and his/her chances or abilities to meet those needs.

Of the aforementioned four ways in which exclusion occurs generally, as suggested by Mareš (2006), ${ }^{30}$ in the case of transport exclusion the latter two have an impact. (a) First, there is the incompatibility of the personal (economic, social, cultural or other) capital of excluded individuals with the demands of the majority society. In this case, the role of incompatible capital is played by the insufficient personal mobility of the excluded individuals. (b) The second way in which transport exclusion occurs is due to structural factors that prevent both individuals and collectivities from being integrated (Mareš 2006). One can consider as such the parameters of transport accessibility affected by institutional, infrastructure and economic factors, which naturally also influence the mobility of individuals.

\footnotetext{
30 See subchapter 'Spatial dimension of social exclusion'.
}

As a result, one can state that in the first case (a), there is exclusion on the basis of internal conditionality and in the second case (b) on the basis of external frameworks (see Fig. 1). Both of these ways in which transport exclusion occurs can be interrelated and the process may also be active on various hierarchical levels simultaneously.

Transport exclusion is an individually perceived process because it depends, among other things, on each individual's specific needs. External frameworks are provided by a vertical or horizontal position within the transport network (see Marada 2006), the extent of inclusion in the transport system, and transport accessibility which can be exactly defined and measured for any given locality and can be relatively the same and stable for its whole population. On the other hand, the internal conditionality constitutes an individual component of transport exclusion which represents the chances of an individual to meet his/her transport needs by means of personal mobility. Both of these factors, transport needs and mobility, are quite individual, being perceived subjectively and differing for each individual. As a result, a locality can suffer from inaccessibility of transport or have a disadvantageous position in a transport network. However, this does not mean that all of its residents are 
excluded in the sphere of transport ${ }^{31}$. Instead, transport exclusion is related more to the feeling of the individual who cannot fully meet his/her own needs according to his/her own ideas due to the transport disadvantage rather than a precisely identifiable phenomenon. This is the reason it is difficult to classify, quantify or directly measure the extent of transport exclusion.

The problem of identifying and possibly classifying exclusion was examined by Preston and Rajé (2007). Based on case studies carried out with the use of quantitative and qualitative data in Bristol, Nottingham and Oxfordshire, they created a three-dimensional socio-spatial scheme of social inclusion and exclusion describing eight types of social exclusion influenced by transport (Preston \& Rajé 2007). This scheme was applied by Horñák (in Rochovská et al. 2016) who points out the possibility of perceiving the types of transport exclusion described as various degrees of transport disadvantage (as suggested in Fig. 2). According to the authors, the type of exclusion arises from a unique combination of three components. The first (a) is personal mobility, which in this case means an individual's mobility in the sense of not only his/her ability, but also the need to be transported, personal demands for transport and the opportunities to meet them individually. This is followed by the second component (b), area mobility, which can be identified with the exposed character of a given area. In this case, high area mobility is typical of core areas, while low area mobility is usual in rural or peripheral areas. In relation to transport, we can approach area mobility as a horizontal transport position (Marada 2006). The third component (c) is accessibility of the area, which determines the accessibility of core areas (such as centres of metropolises, etc.) from a given locality

31 In the same way, Lucas (2012) defines the concept of transport poverty. She defines it as the intersection of social and transport disadvantages, stressing that transport poverty need not necessarily lead to social exclusion of the population of a given locality and the impact on the individual residents of a locality is selective.
(Preston \& Rajé 2007). It is composed of the range of travel opportunities available, representing the extent to which a given locality is integrated (connected) into the transport system. It is defined by both the accessibility itself and the vertical transport position.

Based on the three components and their values in specific cases (high or low), one can distinguish eight types of transport exclusion. For instance, in the case of the first (lowest) degree of exclusion, it may be an area in the centre of a large town with a wide range of transport opportunities, inhabited by a population with a high level of personal mobility. By contrast, the eighth (highest) degree of exclusion primarily relates to rural localities with a low number of transport opportunities and with residents who have such individual demands for transport that they cannot be met by means of personal mobility (see Fig. 2).

Horńák considers the accessibility of an area to be a key factor in the whole scheme. Depending on high/low accessibility (integration/connection to the majority of the society), the eight categories he describes can be divided into those localities which are more or less threatened by transport exclusion. The scheme also highlights the crucial differences in transport exclusion in urban, semi-urban and rural spaces (Preston \& Rajé 2007). On the whole, one can distinguish eight categories of areas differentiated according to their types. They are distinguished with specific transport and mobility characteristics determining the potential exposure of the population to a specific type of transport exclusion. This leads to the assumption that the strategies which people use to cope with a specific (various) type of transport exclusion are various as well.

The impacts of transport exclusion are not the same on all residents of a locality because the process is of a selective nature and its features are perceived individually (Kenyon et al. 2002; Lucas 2012; Lucas et al. 2015; Mackett \& Thoreau 2015). This is why the described categories cannot be perceived as defining areas in which the population is or is not excluded from transport, instead it defines those areas 


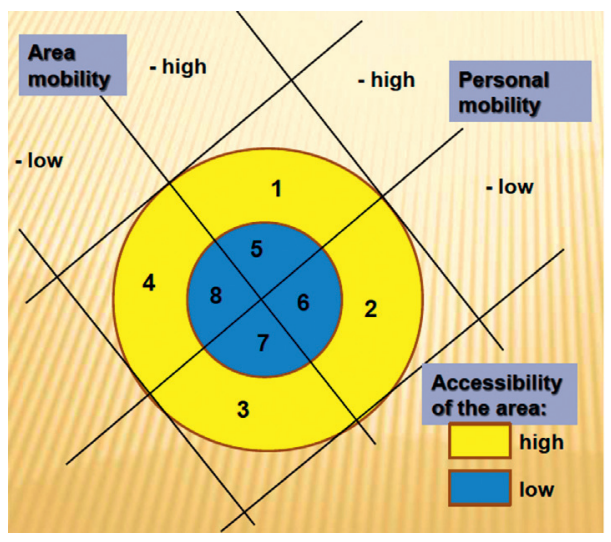

Figure 2. Socio-spatial scheme of the extent of transport exclusion

Source: Preston \& Rajé (2007); modified by Horňák in Rochovská et al. (2016).

with a higher or lower potential of transport exclusion. In fact, there are considerable differences in the resistance/vulnerability towards the manifestations of transport disadvantage of the given localities, especially depending on each individual's personal mobility (Lucas et al. 2001; Lucas 2012). Thus, the extent of exclusion can also change within a single household. This may be caused, e.g., due to differing levels of car ownership and usage. As a result, transport exclusion most threatens those population groups which have limited chances to use individual transport, thus they are forced to rely on public transport. These are women, elderly, children and youths under 18, people with special needs, etc. (Hine \& Mitchell 2003; Engels \& Liu 2011; Shergold \& Parkhurst 2012; Mackett \& Thoreau 2015). In their case, personal mobility is the lowest (according to the Fig. 2) and it is more difficult for them to meet their transport needs through their own efforts. Kenyon then states, with only a slight exaggeration, that "modern landscapes seem to be designed for forty-year old healthy males steering cars" (Kenyon et al. 2002: 212).

As has already been stated, the way social exclusion is directly perceived by the population of specific localities is quite individual. The subjective perception is influenced by objective (rational) factors on the one hand, but also quite irrational ones, on the other. In the latter case, one has to take into consideration not only the needs, but also preferences, habits and the overall lifestyle of every single individual. For this reason, it is quite common for people living in the same locality or even in the same household to perceive their transport exclusion quite differently. This is why the perception of social exclusion is an autonomous feeling of every individual who defines him or herself in this way within the framework of society.

There is still the question of whether a change in the parameters of transport accessibility can serve as an efficient instrument of regional policy with a potential to considerably mitigate the exclusion. In this way, it could improve the accessibility of centres for the population of peripheral or marginal areas, thus allowing them to use the servicing functions of these centres or providing access to the labour market (Nutley 1998; Church et al. 2000). This is naturally associated with the question of the economic profitability of each mode of transport.

Transport exclusion has an impact on excluded individuals by means of barriers to the access to transport which take on various forms (Mackett \& Thoreau 2015). Virtual mobility is one of the factors that can help lower the barriers. Thanks to virtual mobility, there is a considerably increased flow of goods and services. This eventually lowers people's need (necessity) for physical mobility (Kenyon et al. 2002, 2003). On the other hand, this phenomenon can also have a negative impact on the local conventional offer of goods and services. In addition, as in the case of transport exclusion, virtual mobility has a selective impact on society, thus creating another dimension of social inequality.

\section{Conclusion}

The article pursues the objective of discussing the process of social exclusion and its transport conditionality. The author explains the role of the characteristics of transport (in) 
accessibility and (poor) mobility within the framework of the process of social exclusion. On the one hand, this is a factor underlying the appearance and deepening of social inequalities, on the other, it can also enable the integration of excluded individuals and help them overcome social disadvantages.

In general, social exclusion is a process within which some individuals and groups are limited in their participation in the activities that are common in a society. They have no chance to approach social standards. Within the framework of the research of social inequalities, the concept of social exclusion has gradually replaced the concept of poverty, which had been used previously. In this respect, there was a change in the substance of the object of interest itself within the research. It is no longer only focused on the distribution of wealth, but attention is paid to differences in the inclusion of individuals and groups in society. There is no longer an emphasis on the dichotomy of 'rich versus poor', but on the dichotomy of 'integrated versus excluded'. Although both concepts are closely connected, one cannot state unequivocally that all poor people are also socially excluded. In the same spirit, one cannot claim that all the socially excluded must necessarily be poor.

Social inequalities do not directly appear in this process as they are only reproduced. This means that social exclusion does not result from any differentiation in society, but instead is a process within which original spatial differentiations of a society are made even greater. The process can acquire various forms and dimensions depending on the main factors and mechanisms that cause the exclusion. On this basis, specific individuals or groups are limited or even directly excluded from participation in the activities that are common in society.

Transport is one of the factors/mechanisms underlying social exclusion. Social exclusion of an individual or group based on transport (in)accessibility, how far the location is from the destination, and insufficient mobility is a current problem strongly reflected in scientific (Anglo-Saxon in particular) research defined as transport-related social exclusion or just transport exclusion with transport as the underlying factor. This is a complicated, selectively operating differentiation process, which takes into consideration both the social and transport aspects while social viewpoints are primarily related to the fact of social exclusion itself and its influence on each individual's life. The transport aspects reflect the transport conditionality of the process, especially in the form of accessibility (external frameworks) and mobility (internal conditionality). This is the subjectively perceived feeling when an individual does not have the opportunity to meet his/her transport needs. It may happen that within one locality or even one household, transport exclusion may considerably differ for each individual. As a result, the residents of an area with a disadvantageous vertical and horizontal transport position need not be necessarily transport excluded. Transport inaccessibility and low mobility become a problem at the moment they pose certain barriers to individuals, at which point they become socially excluded.

\section{Acknowledgements}

This article was written with the support of the project GAUK 54515: Transport related social exclusion in microregions of Czechia (2015-2017).

Editors' note:

Unless otherwise stated, the sources of tables and figures are the authors', on the basis of their own research. 


\section{References}

ATKINSON R., 2000. Občanstvía boj proti sociální exkluzi v kontextu reformy sociálního státu. Sociální studia, vol. 5, pp. 47-66.

Bauman Z., 2001. Community: Seeking safety in an insecure world. Cambridge, UK: Polity Press.

Burchardt T., Le Grand, J., Piachaud D., 1999. Social exclusion in Britain 1991-1995. Social Policy and Administration, vol. 33, no. 3, pp. 227-244.

Chromý P., JanČ́́́K V., Marada M., HaVlíček T., 2011. Venkov - žitý prostor: regionální diferenciace percepce venkova predstaviteli venkovských obcí $\checkmark$ Česku. Geografie, vol. 116, no. 1, pp. 23-45.

Church A., Frost M., Suluivan K., 2000. Transport and social exclusion in London. Journal of Transport Policy, vol. 7, no. 3, pp. 195-205.

Delbosc A., Currie G., 2011. The spatial context of transport disadvantage, social exclusion and well-being. Journal of Transport Geography, vol. 19, no. 6, pp. 1130-1137.

Engels B., LIU G., 2011. Social exclusion, location and transport disadvantage amongst non-driving seniors in a Melbourne municipality, Australia. Journal of Transport Geography. vol. 19, no. 6, pp. 984-996.

El-Geneidy A., Levinson M., 2006. Access to destinations: Development of accessibility measures. Access to destinations study series, Report no. 1, St. Paul, Minn.: Minnesota Department of Transportation.

Foucault M., Pelikán Č., Petríiček M., Polášek S., Soukup P., Thein K., 1996. Myšlení vnějšku. Praha: Herrmann \& synové.

GIDDENS A., 1998. Düsledky modernity. Praha: SLON.

Granovetter, M. 1973. The strength of weak ties. American Journal of Sociology, vol. 78, no. 6, pp. 1360-1380.

Gregory D., Johnston R., PratT G., Watts M., WhatMORE S. (eds.), 2009. The dictionary of human geography: 5th edition. Chichester: John Wiley \& Sons.

Havlíček T., Chromý P., 2001. Př́spěvek k teorii polarizovaného vývoje území se zaměřením na periferní oblasti. Geografie-Sborník ČGS, vol. 106, no. 1, pp. 1-11.
HINE J., 2008. Transport and social justice [in:] R.D. Knowles, J. Shaw, I. Docherty (eds.), Transport geographies mobilities, flows and spaces. Oxford: John-Wiley/Blackwells.

Hine J., MitChell F., 2003. Transport disadvanatge and social exclusion: Exclusionary mechanisms in transport. Transport and Society Series. Aldershot, UK: Ashgate Publishing Limited.

KENYON S. 2011. Transport and social exclusion: Access to higher education in the UK policy context. Journal of Transport Geography. vol. 19, no. 4, pp. 763-771.

KenYON S., LyONS G., RafferTy J., 2002. Transport and social exclusion: Investigating the possibility of promoting inclusion through virtual mobility. Journal of Transport Geography, vol. 10, no. 3, pp. 207-209.

Kenyon S., Rafferty J., Lyons G., 2003. Social exclusion and transport: A role for virtual accessibility in the alleviation of mobilityrelated social exclusion? Journal of Social Policy, vol. 32, no. 3, pp. 317-338.

KNOWLES R.D., 1993. Research agenda in transport geography for the 1990s. Journal of Transport Geography, vol. 1, no. 1, pp. 1-10.

KOMORNICKI T., RosiK P., ŚlESZYŃSKI P., POMIANOWSKI W., 2010. How can we measure spatial accessibility of the territory of Poland? Europa XXI, vol. 21, Warsaw: Institute of Geography and Spatial Organization PAS, pp. 7-17.

KRAFT S., 2012. A transport classification of settlement centres in the Czech Republic using cluster analysis. Moravian Geographical Reports, vol. 20, no. 3, pp. 38-49.

LEVITAS R., 1996. The concept of social exclusion and the new Durkheimian hegemony. Critical Social Policy, vol. 16, no. 46, pp. 5-20.

LEVITAS R., 2006. The concept and measurement of social exclusion [in:] C. Pantazis, D. Gordon, R. Levitas (eds.), Poverty and Social Exclusion in Britain, Bristol: Policy Press.

Levitas R., Pantazis C., fahmy E., Gordon D., Lloyd E., PATSIOS D., 2007. The multidimensional analysis of social exclusion. Department of Sociology and School for Social Policy, Townsend Centre for the International Study of Poverty \& Bristol Institute for Public Affairs, Bristol: University of Bristol. 
LEWIS O., 1966. The culture of poverty. Scientific American, vol. 215, no. 4, pp. 19-25.

LUCAS K., 2012. Transport and social exclusion: Where we are now. Transport Policy, vol. 20, pp. 105-113.

LUCAS K., GRosvenOR T., SimpSON R., 2001. Transport, the environment and social exclusion. York: Joseph Rowntree Foundation.

MACKETT R., THOREAU R., 2015. Transport, social exclusion and health. Journal of Transport and Health, vol. 2, no. 4, pp. 610-617.

MAsLow A., 1970. Motivation and personality. New York: Harper \& Row.

MARADA M., 2006. Vertikálnía horizontální dopravní poloha středisek osídlení Česka [in:] S. Kraft, K. Mičková, J. Rypl, P. Švec, M. Vančura (eds.), Česká geografie v evropském prostoru - sborník př́spěvků z XXI. sjezdu České geografické společnosti. České Budějovice: Jihočeská univerzita $\checkmark$ Českých Budějovicích.

Marada M., HudeČEk T., 2006. Accessibility of peripheral regions: A case of Czechia. Europa XXI, vol. 15, Warsaw: Institute of Geography and Spatial Organization, pp. 43-49.

MAREŠ P., 2000. Chudoba, marginalizace, sociální vyloučení. Sociologický časopis, vol. 36, no. 3, pp. 285-297.

MAREŠ P., 2002. Marginalizace, sociální exkluze [in:] T. Sirovátka (ed.), Menšiny a marginalizované skupiny v České republice. Brno: Masarykova univerzita, pp. 9-21.

MAREŠ P., 2006. Sociální exkluze, sociální inkluze a sociální koheze: diskurs a realita [in:] T. Sirovátka (ed.), Sociální vyloučení a sociální politika. Brno: Masarykova univerzita, pp. 15-24.

Musil J., Müller J., 2008. Vnitřní periferie v České republice jako mechanismus sociální exkluze. Sociologický časopis, vol. 44, no. 2, pp. 321-348.

NUTLEY S., 1998. Rural areas: The accessibility problém [in:] B. Hoyle, R.D. Knowles (eds.), Modern transport geografy. Michigan: John Wiley \& Sons, pp. 185-215.

PARKIN F., 1971. Class inequality and political order: Social stratification in capitalist and communist societies. London: McGibbon and Kee.

PERCY-SMITH J., 2000. Policy responses to social exclusion: Towards inclusion?. Bickingham-Philadelphia: Open University.
Petrusek M., 1996. Velký sociologickýslovník. Praha: Karolinum.

PIRANI E., 2013. Poverty and social exclusion in Europe: Differences and similarities across regions in recent years. Scientific Meeting SIS, 19-21 June 2013.

Preston J., Rajé F., 2007. Accessibility, mobility and transport-related social exclusion. Journal of Transport Geography, vol. 15, no. 3, pp. 151-160.

RABUŠıC L., 2000. Koho Češi nechtějí. Sociální studia, vol. 5, pp. 67-85.

RATClifFE P., 2004. Race, ethnicity and difference: Imagining the inclusive society. Maidenhead: Open University Press.

RINGEN S., 1988. Direct and indirect measures of poverty. Journal of Social Policy, vol. 17, no. 3, pp. 351-365.

Rochovská A., Drgoncová M., Džupinová E., Horñák M., KáČerová M., Madzinová M., Majo J., Ondoš S. 2016. One place - many worlds: Geographical variability in life strategies in Slovak society. Bratislava: Univerzita Komenského.

Rodrigue J-P., COMTOIS C., SLACK B., 2006. The Geography of transport systems. London: Routledge.

RƯžIČKA M., 2006. Geografie sociální exkluze. Sociální studia, vol. 3, no. 2, pp. 117-132.

Schwanen T., LuCAS K., AkyelKen N., SOlsona D.C., Carrasco J.A., Neutens T., 2015. Rethinking the links between social exclusion and transport disadvantage through the lens of social capital. Transportation Research, part A, vol. 74, pp. 123-135.

SeIDENGLANZ D. 2010. Transport relations among settlement centres in the eastern part of the Czech Republic as a potential for polycentricity. Acta Universitatis Carolinae Geographica, vol. 45, no. 1, pp. 75-89.

SEU 2003. Making the connections: Final report on transport and social exclusion. London: Office of the Deputy Prime Minister.

Sheller M., URRY J., 2006. The new mobilities paradigm. Environment and Planning, vol. 38,no. 2, pp. 207-226.

SHeRgold I., PARKHURST G., 2012. Transport-related social exclusion amongst older people in rural 
Southwest England and Wales. Journal of Rural Studies, vol. 28, no. 4, pp. 412-421.

SibleY D., 1995. Geographies of Exclusion: society and difference in the West. London: Routledge.

SILVER H., 1995. Reconceptualizing social disadvantage: Three paradigms of social exclusion [in:] G. Rodgers, C. Gore, J.B. Figueiredo (eds.), Social exclusion: Rhetoric, reality, response. Geneva: International Labour OrganisationInternational Institute for Labour Studies, pp. 57-80.
StępNiak M., Rosik P., Komornicki T., 2013. Accessibility patterns: Poland case study. Europa XXI, vol. 24, Warsaw: Institute of Geography and Spatial Organization PAS, pp. 77-93.

StROBEL P. 1996. From poverty to exclusion: A wageearning society or a society of human rights? International Social Science Journal, vol. 48, no. 148, pp. 173-189.

TOWNSEND P., 1979. Poverty in the United Kingdom: A survey of household resources and standards of living. Harmondsworth: Penguin Books. 